\title{
МОДЕЛЮВАННЯ ВНУТРІШНЬОРЕГІОНАЛЬНИХ ДИСПРОПОРЦІЙ НА РИНКУ ПРАЦІ УКРАЇНИ
}

\section{MODELING OF INTERNAL REGIONAL DISPROPORTIONS IN THE LABOR MARKET OF UKRAINE}

\author{
Дериховська Вікторія Ігорівна \\ кандидат економічних наук, доцент, \\ Харківський національний економічний університет імені Семена Кузнеця \\ ORCID: https://orcid.org/0000-0002-6999-6104 \\ Derykhovska Viktoriia \\ Simon Kuznets Kharkiv National University of Economics
}

\begin{abstract}
Стаття присвячена дослідженню нерівномірності розвитку регіональних ринків праці, спровокованій наявною диспропорційністю між попитом та пропозицією на робочу силу. Визначено, що зовнішня трудова та освітня міграція, несправедлива система оплати праці, відсутність інорраструктури та розвинутого підприємництва - це коло проблем, що істотно гальмують розвиток регіональних ринків праці. Сформовано систему соціально-економічних показників, що характеризують поточний стан ринку праці територій та, використовуючи кластерний аналіз, згруповано регіони країни в однорідні кластерні утворення й надано їх комплексну характеристику. Досліджено міграцію регіонів України між кластерами у 2019 р. порівняно 32010 р. та проаналізовано причини, що її викликали. Окреслено напрямки розвитку регіональних ринків праці в контексті діджиталізації та «Індустрії 4.0».
\end{abstract}

Ключові слова: ринок праці, регіон, кластерний аналіз, моделювання, диспропорційність, попит, пропозиція.

Статья посвящена исследованию неравномерности развития региональных рынков труда, спровоцированной имеющейся диспропорцией между спросом и предложением на рабочую силу. Определено, что внешняя трудовая и образовательная миграция, несправедливая система оплаты труда, отсутствие инфраструктуры и развитого предпринимательства - это круг проблем, которые существенно тормозят развитие региональных рынков труда. Сформирована система социально-экономических показателей, характеризующих текущее состояние рынка труда территорий и, используя кластерный анализ, сгруппированы регионы страны в однородные кластерные образования и предложено их комплексную характеристику. Исследовано миграцию регионов Украины между кластерами в 2019 г. по сравнению с 2010 г., а также проанализированы причины, что ее вызвали. Определены направления развития региональных рынков труда в контексте диджитализации и «Индустрии 4.0».

Ключевые слова: рынок труда, регион, кластерный анализ, моделирование, диспропорция, спрос, предложение.

The article is devoted to the study of the uneven development of regional labor markets, provoked by the existing disproportion between supply and demand for labor. The Ukrainian labor market is characterized by external labor and educational migration, an unfair wage system, lack of infrastructure, and undeveloped entrepreneurship. A significant range of problems significantly hamper its adaptation to new economic conditions makes it impossible to implement the experience of developed countries on the effective and rational combination of market and the government mechanisms for regulating relations in the labor market. Moreover, these negative trends are deepening at the regional level, which is also explained by the existing asymmetry and disproportion of the development of the country's territories, and significantly inhibits the development of regional labor markets. That is why it is important today to monitor and assess the current state of regional labor markets, their comparative analysis to reduce the uneven development of territories, and effective management of intra-regional disparities in the labor market of Ukraine. In the course of the research comparative analysis, statistical analysis, cluster method was used. The average monthly wage, the level of the economically active population, the unemployment rate, the workload of registered unemployed per vacancy, and the migration balance are a list of socio-economic indicators that characterize the current state of the labor market and provided a statistical basis for cluster analysis. As a result of the research, the regions of the country are grouped into homogeneous cluster formations and their complex characteristics are 
given. The fact of significant disproportion and asymmetry in the level of development of regional labor markets is emphasized. The migration of the regions of Ukraine between clusters in 2019 compared to 2010 is studied and the reasons that caused it are analyzed. The directions of development of regional labor markets in the context of decentralization, digitalization, and "Industry 4.0" are outlined. It is noted that the main vector of development in solving current problems should be innovative development, which provides comprehensive support for entrepreneurship development, development of extensive infrastructure of regions, reform of migration policy, wages system and education system according to the requests of the business community, efficient use of available resources and labor potential taking into account territorial specialization.

Keywords: labor market, region, cluster analysis, modeling, disproportion, demand, supply.

Постановка проблеми. На тлі глобалізаційних процесів, поглиблення світового поділу праці, посилення міжнародних господарських взаємозв'язків та мінливості міграційних потоків питання моніторингу та оцінки стану національного ринку праці з метою визначення тенденцій його розвитку $є$ вкрай актуальним як на рівні економіки України, так і для світового ринку праці в цілому.

Підпорядковуючись законам попиту та пропозиції, конкуренції та вартості, поточне фрункціонування вітчизняного ринку праці стикається зі значним колом проблем, серед яких: широкомасштабна трудова та освітня міграції, наявність суттєвої структурної диспропорційності між попитом на робочу силу та її пропозицією, зростання рівня безробіття та несрормальної (тіньової) зайнятості, занепад регіональних ринків праці основних галузей господарства, низький соціальний захист непрацездатних громадян. Все це істотно гальмує адаптацію українського ринку праці до нових умов господарювання, унеможливлює впровадження досвіду розвинутих країн щодо ефрективного та раціонального поєднання ринкових та державних механізмів регулювання відносин на ринку праці.

Аналіз останніх досліджень і публікацій. Питання дослідження та оцінки нерівномірності та асиметричності розвитку регіональних ринків праці знайшло своє висвітлення у працях вітчизняних та закордонних вчених, серед як доцільно відмітити вклад Романова А., Швидкої Г., Петрової І., Близнюк В., Давидової І., Гатило В. та Новака І. [1-5].

Виділення невирішених раніше частин загальної проблеми. Безумовно, на механізм фрункціонування вітчизняного ринку праці впливає значне коло сракторів правового, соціально-економічного, демографрічного та освітньо-культурного характеру, які мають певну специоріку прояву на регіональному рівні. Адже зазначені вище проблеми суттєво поглиблює існуюча дисреренціація регіональних ринків праці, наявність депресивних регіонів 3 особливо напруженою ситуацією на ринку праці, значно вищим за середній рівнем безробіття за одночасно обмеженою можливістю до працевлаштування, розвитку підприємництва та впровадження інновацій, що, в свою чергу, свідчить про недоліки державної системи регулювання всіх аспектів зайнятості та безробіття у регіональному розрізі.

Формулювання цілей статті (постановка завдання). Обґрунтовано виникає необхідність вдосконалення процесів моніторингу та оцінки поточного й перспективного станів регіональних ринків праці, їх компаративний аналіз задля зменшення асиметричності та нерівномірності розвитку територій й ефективного управління процесами регулювання внутрішньорегіональних диспропорцій на ринку праці України.

Виклад основного матеріалу дослідження. 3 метою комплексної оцінки стану регіональних ринків праці використано один 3 поширених методів моделювання багатовимірних процесів - кластерний аналіз. Його перевагами серед інших методів $€$ широкий прикладний характер застосування в різних областях, відсутність обмежень щодо кількості групувальних ознак, кількості та виду об'єктів дослідження (вихідні дані довільної природи), а також він відноситься до групи надійних, наочних, швидких та доволі простих в інтерпретації методів класифрікації об'єктів [6].

В якості інфрормаційної бази дослідження використано наявну систему соціально-економічних показників, які всебічно характеризують стан ринку праці окремих територій, а саме середня місячна заробітна плата (як економічна передумова забезпечення та покращення якості життя, чинник матеріального стимулювання до профресійного розвитку та високо-продуктивної праці); рівень економічно активного населення (характеризує наявний трудовий потенціал через відношення кількості економічно активного населення віком 15-70 років до всього населення зазначеного віку, тобто це відносний показник забезпеченості певного регіону достатньою пропозицією робочої сили для задоволення наявних потреб сфери виробництва товарів та послуг); рівень безро- 
біття (відношення кількості безробітних віком 15-70 років до економічно активного населення зазначеного віку, виступає індикатором недовикористання економічного потенціалу суспільства, що, в свою чергу, знижує конкурентоспроможність регіонів країни та перешкоджає ïx економічному зростанню); навантаження зареєстрованих безробітних на одну вакансію (відношення кількості зареєстрованих у державній службі зайнятості безробітних громадян до кількості вільних робочих місць (вакантних посад), заявлених роботодавцями, показник, що характеризує співвідношення попиту та пропозиції робочої сили); міграційне сальдо (розраховується як різниця між кількістю прибулих та вибулих осіб за певний період та характеризує зміну чисельності населення території за рахунок механічного руху).

Задля забезпечення співставленності та порівнянності даних, статистична інорормація збиралась станом на грудень 2010 р. та 2019 р. Джерелом статистичних даних виступила Державна служба статистики України [7].

\begin{tabular}{|l|c|c|c|c|}
\hline \multirow{2}{*}{$\begin{array}{l}\text { Cluster } \\
\text { Number }\end{array}$} & \multicolumn{4}{|c|}{$\begin{array}{l}\text { Euclidean Distances between Clusters (Spreadsheet2) } \\
\text { Distances below diagonal } \\
\text { Squared distances above diagonal }\end{array}$} \\
\cline { 2 - 6 } No. 1 & 0,000000 & 0,860716 & 1,036797 & 5,615562 \\
\hline No. 2 & 0,927748 & 0,000000 & 1,002406 & 3,537160 \\
\hline No. 3 & 1,018232 & 1,001202 & 0,000000 & 5,615203 \\
\hline No. 4 & 2,369718 & 1,880734 & 2,369642 & 0,000000 \\
\hline
\end{tabular}

Рис. 1. Евклідові відстані між кластерами

Джерело: авторська розробка
Моделювання методом кластерного аналізу виконувалось у ППП Statictica 10.0. Доцільно зазначити, що для більшої наочності та детального уявлення про структуру даних, а також обґрунтування кількості виділених кластерів на першому етапі було задіяно ієрархічно дивізимний метод Варда, а потім ітеративний метод k-середніх. Зокрема графрічний аналіз визначення кількості кластерних груп на підставі використання дендрограми, грасріку процесу об'єднання та таблиці об'єднання об'єктів, дозволили припустити, що найбільш доцільним $€$ розбиття досліджуваної сукупності регіонів за основними показниками стану ринку праці у 2019 р. на 4 кластери (рис. 1-2):

Згідно до матриці відстаней між кластерами (рис. 1) можна підтвердити якість проведеної кластеризації. Дотримуючись вимог внутрішньої однорідності та зовнішньої ізольованості, регіони України було об'єднано в 4 однорідні групи, представники кожної з яких наведено на рис. 2.

Аналіз рис. 2 дозволяє виділити репрезентантів для кожного кластеру, зокрема для першого кластеру - це Тернопільська область (найближче розташована область до центру кластера), другого Чернівецька, третього - Херсонська та четвертого - Київська область та м. Київ.

Візуалізація результатів кластеризації, що наочно демонструє характер розбиття регіонів на кластери, представлена на рис. 3.

Наступним етапом є перевірка якості проведеної кластеризації. Так викорис-

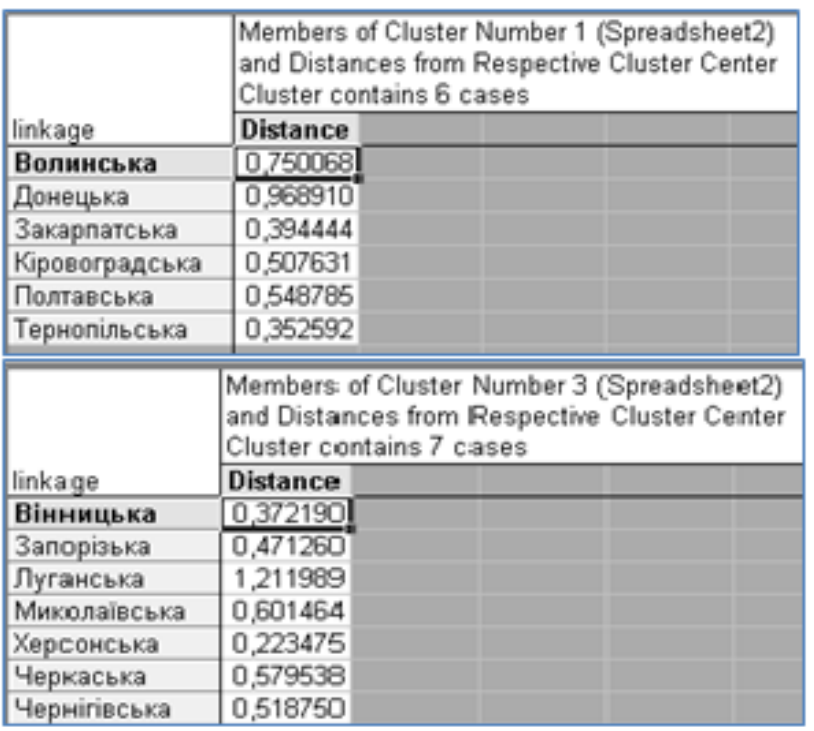

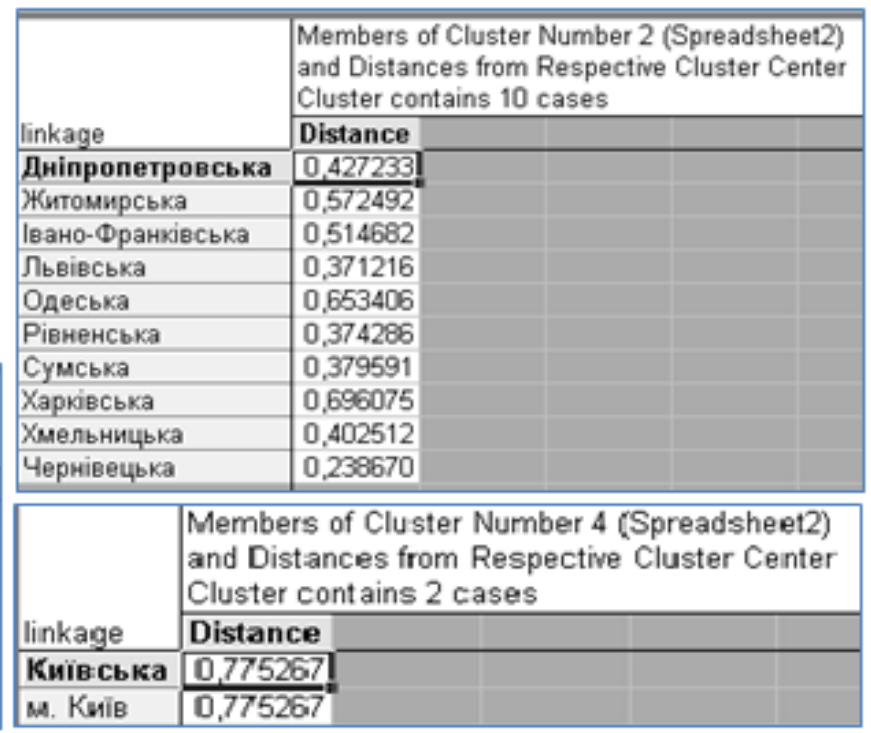

Рис. 2. Перелік регіонів, що увійшли до кожного кластеру у 2019 р. 


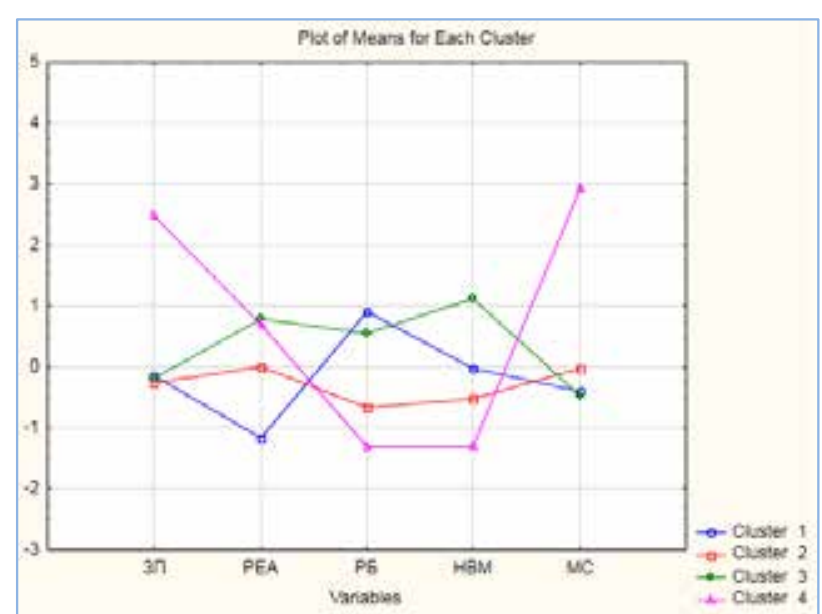

Рис. 3. Графічне середніх значень показників за кластерами

Джерело: авторська розробка

товуючи дискримінантний аналіз було отримано наступні результати: значення статистики Уилкса (Wilks' Lambda = 0,0106) наближуються

\begin{tabular}{|c|c|c|c|c|c|}
\hline \multirow[b]{2}{*}{ Group } & \multicolumn{5}{|c|}{$\begin{array}{l}\text { Classification Matrix (Spreadsheet2) } \\
\text { Rows: Observed classifications } \\
\text { Columns: Predicted classifications }\end{array}$} \\
\hline & \begin{tabular}{|c|} 
Percent \\
Correct
\end{tabular} & $\begin{array}{c}G=1: 1 \\
p=\overline{2} 4000\end{array}$ & $\begin{array}{c}G \_2: 2 \\
p=, 40000\end{array}$ & $\begin{array}{c}G .3: 3 \\
p=, 28000\end{array}$ & $\begin{array}{c}G=4: 4 \\
p=\overline{0} 8000\end{array}$ \\
\hline G_1:1 & 100,0000 & E & 0 & 0 & 0 \\
\hline$G \_2: 2$ & 100,0000 & 0 & 10 & 0 & 0 \\
\hline$G_{-} 3: 3$ & 100,0000 & 0 & 0 & 7 & 0 \\
\hline G $4: 4$ & 100,0000 & [ & [ & 0 & 2 \\
\hline Total & 1000,0000 & $\overline{\bar{E}}$ & $\overline{10}$ & $\overline{77}$ & 2 \\
\hline
\end{tabular}

Рис. 4. Класифрікаційна матриця

Джерело: авторська розробка

до 0, що свідчить про гарну дискримінацію об'єктів, а також відповідно до класифрікаційної матриці (рис. 4) та таблиці класифрікації можна зробити висновок, що відсутні випадки неправильного віднесення об'єктів до кластерів. Тобто, кластеризація є коректною.

Комплексний аналіз результатів кластеризації дозволив запропонувати наступну характеристику наведених у табл. 1 кластерів.

Загальна характеристика кластерів

Таблиця 1

\section{за станом основних показників ринку праці у 2019 р.}

\begin{tabular}{|c|c|c|}
\hline $\begin{array}{c}\text { № } \\
\text { кластера }\end{array}$ & $\begin{array}{l}\text { Перелік регіонів, що } \\
\text { входять до кластеру }\end{array}$ & Основні характеристики кластеру \\
\hline $\begin{array}{l}\text { Перший } \\
\text { кластер }\end{array}$ & $\begin{array}{l}\text { Волинська, Донецька, } \\
\text { Закарпатська, } \\
\text { Кіровоградська, } \\
\text { Полтавська, } \\
\text { Тернопільська }\end{array}$ & $\begin{array}{l}\text { Регіони зі складним становищем на ринку праці. Для } \\
\text { них властиво негативне сальдо міграції, дефріцит } \\
\text { економічно активного населення та високий рівень } \\
\text { безробіття. Регіони характеризуються низьким рівнем } \\
\text { попиту на робочу силу та заробітною платою нижче за } \\
\text { середній рівень по країні. }\end{array}$ \\
\hline $\begin{array}{l}\text { Другий } \\
\text { кластер }\end{array}$ & $\begin{array}{l}\text { Дніпропетровська, } \\
\text { Житомирська, } \\
\text { Івано-Франківська, } \\
\text { Львівська, Одеська, } \\
\text { Рівненська, Сумська, } \\
\text { Харківська,Чернівецька, } \\
\text { Хмельницька }\end{array}$ & $\begin{array}{l}\text { Регіони з середнім рівнем розвитку ринку праці. } \\
\text { Ці регіони мають усереднені значення показників, } \\
\text { що характеризують стан ринку праці. Зокрема в } \\
\text { них створено передумови для розвитку ринкової } \\
\text { інфраструктури, створюються нові робочі місця, } \\
\text { пропонується більш висока оплата праці. Однак, } \\
\text { для цих регіонів властива як міжрегіональна, так і } \\
\text { міждержавна трудова міграція. }\end{array}$ \\
\hline $\begin{array}{l}\text { Третій } \\
\text { кластер }\end{array}$ & $\begin{array}{l}\text { Вінницька, } \\
\text { Запорізька, Луганська, } \\
\text { Миколаївська, } \\
\text { Херсонська, Черкаська, } \\
\text { Чернігівська }\end{array}$ & $\begin{array}{l}\text { Регіони з низьким рівнем розвитку ринку праці. У цих } \\
\text { регіонах наявний трудовий потенціал використовується } \\
\text { неесективно, що підтверджується високим рівнем } \\
\text { безробіття та значним навантаженням на одне вакантне } \\
\text { місце. Трудова міграція, що притаманна цим областям, } \\
\text { істотно спустошує трудові резерви територій та значно } \\
\text { гальмує розвиток ринку праці. }\end{array}$ \\
\hline $\begin{array}{l}\text { Четвертий } \\
\text { кластер }\end{array}$ & Київська, м. Київ & $\begin{array}{l}\text { Регіони з високими показниками розвитку ринку праці, } \\
\text { пропонують високу оплату праці, мають значний } \\
\text { трудовий потенціал, позитивне сальдо міграції та } \\
\text { найбільшу потребу у працівниках, а також найнижчий } \\
\text { рівень безробіття та незначне навантаження на } \\
\text { одне вакантне місце. Ці регіони є привабливими для } \\
\text { інвесторів, мають розвинуту та розгалужену ринкову } \\
\text { інфрраструктуру, в них створено відповідні умови для } \\
\text { розвитку підприємництва тощо. }\end{array}$ \\
\hline
\end{tabular}


Порівнюючи отримані результати розподілу регіонів за основними показниками ринку праці у 2019 р. $з$ кластеризацією регіонів у 2010 р., доцільно відмітити, що за останні 10 років значних позитивних змін зазнали ринки праці Вінницького, Івано-Франківського, Рівненського, Сумського та Хмельницького регіонів, в той же час негативну тенденцію кластерної міграції можна спостерігати в Одеському, Донецькому, Закарпатському, Кіровоградському, Луганському та Полтавському регіонах. Безумовно, для деяких областей зазначені зміни відбулися на тлі воєнного консрлікту на сході країни та відповідно зазнало загострення соціально-економічне становище територій (Луганська та Донецька області). Інші регіони не змогли в достатній мірі адаптуватися до нестабільності політичної ситуації в країні, рефрорм на ринку праці, протистояти трудовій та освітній міграції, вирішити проблеми з тіньовою зайнятістю та нелегальним веденням бізнесу, структурними диспропорціями тощо. Незмінним, нажаль, залишається фракт наявності значної диспропорційності та асиметричності у рівні розвитку регіональних ринку праці.

Проблему нерівномірності розвитку територій повинна частково вирішити децентралізація, яка, шляхом об'єднання матеріальних, трудових та земельних ресурсів громад, мала створити необхідні умови для концентрації трудового потенціалу та розвитку інорраструктури територій, тобто новостворена адміністративна одиниця повинна стати більш потужною та конкуренто-спроможною. Однак примусовий характер впровадження рефрорми децентралізації загострив проблеми неузгодженості дій та слабкої комунікації з галузевими міністерствами та відомствами, недостатньо досвідченим менеджментом громад. Все це відтерміновує вирішення поточних та довгострокових питань на регіональних ринках праці, що, в свою чергу, ускладнює та гальмує збалансування внутрішньорегіональних диспропорцій щодо досягнення стратегічних цілей розвитку територій країни, максимальну реалізацію їх трудового потенціалу, створення справедливих та гідних умов праці, пропозиції належного матеріального заохочення до праці, задоволення вимог роботодавців щодо якісної професійної підготовки працівників та розробки й впровадження заходів для повернення трудових мігрантів.

Без врахування світових трендів та глобалізаційних змін, розуміння поточної законодавчої, економічної, соціально-демограсрічної ситуації в Україні, а також прогнозування ії стану у майбутньому, неможливе ефективне та збалансоване фрункціонування регіональних ринків праці. Це, перш за все, стосується всеосяжного проникнення IT та цифрових технологій, автоматизації у всі ссрери соціально-економічного життя суспільства. Діджиталізація («технологічний уряд 3.0») та платорорма «Індустрія 4.0» змусили уряди країн переосмислити сталі способи ведення бізнесу, врахувати особливості вертикальної та горизонтальної IT інтеграції, комбінувати інфрормаційно-комунікаційні технології, створювати бізнес-моделі, засновані на інноваціях, хайтек-технологіях, кібер-системах та штучному інтелекті тощо [3; 8; 9].

Висновки. Поточний стан України як сировинної, деіндустріалізованої країни Східної Європи безумовно негативно віддзеркалюється на фрункціонування вітчизняного ринку праці. Зокрема це проявляється у відсутності попиту на робочу силу, значній диференціації в оплаті праці, зростаючому відтоку трудового потенціалу закордон і т.д. Відповідно тенденції та напрямки діджиталізації економіки мають бути враховані під час модернізації та рефрормування регіональних ринків праці. Головним вектором розвитку має стати інноваційний розвиток, що передбачає всебічну підтримку розвитку підприємництва, розбудову розгалуженої інфрраструктури регіонів, реформування системи освіти відповідно за запитів бізнесспільноти, ефективне використання наявного ресурсного та трудового потенціалу з врахуванням територіальної спеціалізації, рефрормування системи оплати праці. Це, в свою чергу, створить умови для покращення інвестиційного клімату в регіонах, підвищить ступень їх адаптивності до дестабілізуючих зовнішніх та внутрішніх впливів, докорінно змінить ситуацію з освітньою та трудовою міграцією, а, отже, поступово збалансує диспропорційність між попитом та пропозицією як на внутрішньорегіональних, так і на національному ринках праці.

\section{СПИСОК ВИКОРИСТАНИХ ДЖЕРЕЛ:}

1. Романов А. Асиметрії ринку праці та механізми їх регулювання в умовах досягнення цілей сталого розвитку. Економічний аналіз. 2019. Том 29. № 4. С. 58-66.

2. Швидка Г.Ю. Регіональні особливості ринку праці України. Демографрія та соціальна економіка. 2010. № 2. C. $160-167$. 
3. Давидова І.О., Гатило В.П. Дослідження стану ринка праці в Україні як основи для формування іміджстратегії підприємств у рамках Iндустрії 4.0. URL: https://goo-gl.su/MOepONW (дата звернення: 28.01.2021).

4. Петрова І.Л., Близнюк В.В. Український ринок праці: імперативи та можливості змін : колективна монографія. Київ : ІЕП НАН України, 2018. 356 с.

5. Новак І.М. Соціальний розвиток регіонів України: оцінка та напрями зменшення диспропорцій : монографрія. Донецьк-Київ : ІЕП, ІСД НАН України, 2008. 185 с.

6. Раєвнєва О.В. Статистичне моделювання та прогнозування : Навчальний посібник. Харків : ВД «ІНЖЕК». 2014. $578 \mathrm{c}$.

7. Державна служба статистики України. URL: http://www.ukrstat.gov.ua/ (дата звернення: 27.01.2021).

8. Degris C. Here are the new social risks of the Fourth Industrial Revolution. URL: https://www.socialeurope.eu/ here-are-the-new-social-risks-of-the-fourth-industrial-revolution (дата звернення: 28.01.2021).

9. Наумова М.А. Вплив глобальних викликів на функціонування ринку праці. Бізнес Інфоом. 2019. № 1. C. $40-49$.

\section{REFERENCES:}

1. Romanov A. (2019) Asymetrii rynku pratsi ta mekhanizmy yikh rehuliuvannia v umovakh dosiahnennia tsilei staloho rozvytku [Asymmetries of the labor market and mechanisms of their regulation in terms of achieving sustainable development goals]. Ekonomichnyi analiz, tom 29, no. 4, pp. 58-66.

2. Shvydka H.Yu. (2010) Rehionalni osoblyvosti rynku pratsi Ukrainy [Regional features of the labor market of Ukraine]. Demohrafiia ta sotsialna ekonomika, no. 2, pp. 160-167.

3. Davydova I.O., \& Hatylo V.P. Doslidzhennia stanu rynka pratsi v Ukraini yak osnovy dlia formuvannia imidzh-stratehii pidpryiemstv u ramkakh Industrii 4.0 [Research of the state of the labor market in Ukraine as a basis for the formation of the image strategy of enterprises within Industry 4.0]. Available at: https://goo-gl.su/MOepONW (accessed 28 January 2021).

4. Petrova I.L., \& Blyzniuk V.V. (2018) Ukrainskyi rynok pratsi: imperatyvy ta mozhlyvosti zmin [Ukrainian labor market: imperatives and opportunities for change]: kolektyvna monohrafiia [a mogograph]. Kyiv: IEP NAN Ukrainy, 356 p. (in Ukrainian)

5. Novak I.M. (2008) Sotsialnyi rozvytok rehioniv Ukrainy: otsinka ta napriamy zmenshennia dysproportsii [Social development of the regions of Ukraine: assessment and directions of reducing disparities]: monohrafiia [a mogograph]. Donetsk-Kyiv: IEP, ISD NAN Ukrainy, 185 p. (in Ukrainian)

6. Raievnieva O.V. (2014) Statystychne modeliuvannia ta prohnozuvannia [Statistical modeling and forecasting]: Navchalnyi posibnyk [a textbook]. Kharkiv: VD «INZhEK», 578 p. (in Ukrainian)

7. Derzhavna sluzhba statystyky Ukrainy [State Statistics Service of Ukraine]. Available at: http://www.ukrstat.gov.ua/ (accessed 27 January 2021).

8. Degris C. Here are the new social risks of the Fourth Industrial Revolution. Available at: https://www.socialeurope.eu/here-are-the-new-social-risks-of-the-fourth-industrial-revolution (accessed 28 January 2021).

9. Naumova M.A. (2019) Vplyv hlobalnykh vyklykiv na funktsionuvannia rynku pratsi [The impact of global challenges on the functioning of the labor market]. Biznes Inform, no. 1, pp. 40-49. 